Research

\title{
Confirmation of emergence of mutations associated with atovaquone-proguanil resistance in unexposed Plasmodium falciparum isolates from Africa
}

\author{
Christian T Happi*1,2, Grace O Gbotosho1 ${ }^{1}$, Onikepe A Folarin ${ }^{1}$, \\ Danny Milner ${ }^{2}$, Ousmane Sarr ${ }^{3}$, Akintunde Sowunmi ${ }^{1}$, Dennis E Kyle ${ }^{4}$, \\ Wilbur K Milhous ${ }^{4}$, Dyann F Wirth ${ }^{2}$ and Ayoade MJ Oduola ${ }^{5}$
}

\begin{abstract}
Address: ${ }^{1}$ Malaria Research Laboratories, Institute for Advanced Medical Research and Training, College of Medicine, University of Ibadan, Nigeria, ${ }^{2}$ Department of Immunology and Infectious Diseases, Harvard School of Public Health, Boston, MA, USA, ${ }^{3}$ Laboratory of Bacteriology and Virology, Dantec Hospital, Dakar, Senegal, ${ }^{4}$ Division of Experimental Therapeutics, Walter Reed Army Institute of Research, Silver Springs, MD, USA and ${ }^{5}$ Special Programme for Research and Training in Tropical Diseases (WHO/TDR), Geneva, Switzerland

Email: Christian T Happi* - chappi@hsph.harvard.edu; Grace O Gbotosho - solagbotosho@yahoo.co.uk;

Onikepe A Folarin - onikepefolarin@yahoo.com; Danny Milner - dmilner@hsph.harvard.edu; Ousmane Sarr - osarr@hsph.harvard.edu; Akintunde Sowunmi - asowunmi@hotmail.com; Dennis E Kyle - dennis.kyle@us.army.mil; Wilbur K Milhous - wilbur.milhous@us.army.mil; Dyann F Wirth - dfwirth@hsph.harvard.edu; Ayoade MJ Oduola - oduolaa@who.int

* Corresponding author
\end{abstract}

Published: 04 October 2006

Malaria Journal 2006, 5:82 doi:10.1186/1475-2875-5-82

This article is available from: http://www.malariajournal.com/content/5/I/82

(c) 2006 Happi et al; licensee BioMed Central Ltd.

This is an Open Access article distributed under the terms of the Creative Commons Attribution License (http://creativecommons.org/licenses/by/2.0), which permits unrestricted use, distribution, and reproduction in any medium, provided the original work is properly cited.

\begin{abstract}
Background: In vitro and in vivo resistance of Plasmodium falciparum to atovaquone or atovaquoneproguanil hydrochloride combination has been associated to two point mutations in the parasite cytochrome b (cytb) gene (Tyr268Ser and Tyr268Asn). However, little is known about the prevalence of codon-268 mutations in natural populations of $P$. falciparum without previous exposure to the drug in Africa.

Methods: The prevalence of codon-268 mutations in the cytb gene of African P. falciparum isolates from Nigeria, Malawi and Senegal, where atovaquone-proguanil has not been introduced for treatment of malaria was assessed. Genotyping of the cytb gene in isolates of $P$. falciparum was performed by PCRrestriction fragment length polymorphism and confirmed by sequencing.

Results: 295 samples from Nigeria (III), Malawi (9I) and Senegal (93) were successfully analyzed for detection of either mutant Tyr268Ser or Tyr268Asn. No case of Ser268 or Asn268 was detected in cytb gene of parasites from Malawi or Senegal. However, Asn268 was detected in five out of 1 II (4.5\%) unexposed $P$. falciparum isolates from Nigeria. In addition, one out of these five mutant Asn268 isolates showed an additional cytb mutation leading to a Pro266Thr substitution inside the ubiquinone reduction site.

Conclusion: No Tyr268Ser mutation is found in cytb of $P$. falciparum isolates from Nigeria, Malawi or Senegal. This study reports for the first time cytb Tyr268Asn mutation in unexposed $P$. falciparum isolates from Nigeria. The emergence in Africa of $P$. falciparum isolates with cytb Tyr268Asn mutation is a matter of serious concern. Continuous monitoring of atovaquone-proguanil resistant $P$. falciparum in Africa is warranted for the rational use of this new antimalarial drug, especially in non-immune travelers.
\end{abstract}




\section{Background}

The rapid development and spread of drug resistant Plasmodium falciparum is a serious global health problem in the management of malaria infections. Increasing resistance to antimalarials by $P$. falciparum has led to renewed search for alternative effective new drugs with unique cellular targets. In the 1990s, the urgent need for new antimalarial drugs for treatment and chemoprophylaxis led to the development of atovaquone (2-[trans-4-(4'-chlorophenyl) cyclohexyl]-3-hydroxy-1,4-hydroxynaphtoquinone)[1]. This anti-malarial compound has broad spectrum activity against human protozoan pathogens $[2,3]$ among which are the Plasmodium spp. $[4,5]$. Atovaquone is a potent and specific inhibitor of the cytochrome $b c 1$ (cytbc1) complex [6,7], an essential respiratory enzyme present in the inner mitochondrial membrane. Unfortunately, in the Plasmodium genus and especially in P. falciparum, atovaquone when used as a single agent showed a high frequency of recrudescence $[8,9]$ and recrudescing parasites are approximately 1,00010,000 fold more resistant [10-12]. In order to minimize the risk of resistance development, a fixed synergistic combination of atovaquone with proguanil hydrochloride was developed under the trade name of Malarone ${ }^{\circledR}$. It has been suggested that proguanil at lower doses acts synergistically to enhance the ability of atovaquone to collapse the mitochondrial membrane potential without affecting electron transport inhibition [13]. However, the exact mechanism of synergy between these two drugs remains unknown. The combination of atovaquone-proguanil (AP) can achieve a cure rate of 99\%-100\% $[9,14-$ 16]. Despite its high activity against the malaria parasite, the cost of AP treatment has until now restricted its use to western non-immune adult and children [17] travelers and some European military personnel [18]. Unfortunately, there is growing evidence that malaria parasites may quickly develop resistance to AP by mutation of amino acid residues located in or near the atovaquonebinding site on $c y t b$ [19-23]. Only a decade after its introduction, AP treatment failures have been reported in nonimmune travelers returning from Africa. Nearly all cases are from individuals who have visited West Africa. [11,22,24-27]. AP treatment failures in a significant number of these patients have been genetically linked to point mutations in the atovaquone-binding site of the $P$. falciparum mitochondrial $c y t b$ gene(Tyr268Ser or Tyr268Asn or Tyr268Cys) [11,12,22,24-28].

Recently, Kessl and colleagues [7] used site directed mutagenesis in Saccharomyces cerevisiae to genetically and biochemically confirm the linkage of atovaquone/AP resistance to $c y t b$ mutations (Tyr268Ser and Tyr268Asn) and to explain at the molecular level the mechanism of malaria parasites resistance to this drug. Cytb Tyr268Ser and Tyr268Asn mutations, have been used as a potential molecular marker of AP resistance in non-immune travelers who present with malaria after visiting disease endemic areas $[11,12,22,24-30]$.

It has been suggested that AP resistant phenotypes might arise through strong selection of resistant sub-populations harboring resistance associated mutations [12,29] or, through a mutagenic capacity of atovaquone on $P$. falciparum parasites alone or even in the AP combination $[19,20,25]$ However, very little is known on the background/baseline prevalence of codon-268 mutations in natural populations of $P$. falciparum without previous exposure to the drug in Africa. In this study, the prevalence of codon-268 mutations in the $c y t b$ gene of $P$. falciparum isolates from Nigeria, Malawi and Senegal was assessed.

Although, no Tyr268Ser mutation is found in $c y t b$ of $P$. falciparum isolates from Nigeria, Malawi or Senegal, the presence of the $c y t b$ Tyr268Asn mutation is reported for the first time in unexposed $P$. falciparum isolates from Nigeria. The emergence of $c y t b$ Tyr268Asn mutation in $P$. falciparum populations of Africa is a matter of serious concern, since the AP combination has not been widely used yet in West Africa.

\section{Methods \\ Study areas}

The studies were conducted at the Malaria Research Laboratory, College of Medicine, University of Ibadan, Nigeria (2003-2005), the Queen Elizabeth Central Hospital (within the Blantyre Malaria Project), University of Malawi College of Medicine, Blantyre, Malawi (19962005) and the Malaria Research Laboratory, Hopital Le Dantec, Dakar, Senegal (2002-2005).

The Human Subjects Committee of Harvard School of Public Health in Boston, the Institutional Review Committees at the University of Ibadan, Ibadan, Nigeria, the ethical review committee at the College of Medicine, University of Blantyre, Malawi and the Ethics Committee of the Senegalese Ministry of Health approved the protocols used in these studies. Documented informed consent was obtained from parents/guardians.

\section{Biological materials}

Peripheral blood samples preserved on 3 MM Whatman ${ }^{\circledR}$ filter paper were obtained from Nigerian children with microscopically confirmed P. falciparum. Parasites DNA samples from Nigerian patients used in this study are the same with those reported in a previous study describing the association between mutations in parasites $d h f r$ and dhps genes and in vivo sulfadoxine-pyrimethamine resistance [31]. 
Samples from Senegal were collected from patients attending a health clinic in Pikine, a suburb of the capital city, Dakar. A drop of blood obtained from each study participant at enrollment was blotted unto filter paper (ISOCODE, Schleicher \& Schuell). The samples were air dried and stored in plastic bags containing silica gel.

In Malawi, parasite DNA was obtained from either an archive of material collected from 1996 to 2004 or as part of an ongoing study of genetic diversity from 2003 to the present. Samples were collected from patients ranging from infants through adult with a spectrum of clinical disease from asymptomatic carriage to severe disease although this information was not used for analysis (i.e., the 91 samples represent the "population" of parasites for Malawi). All samples were either exempt from consent (archived parasite DNA previously extracted and stored at $-80^{\circ} \mathrm{C}$ ) or consented for collection of parasite DNA (fresh samples of peripheral blood extracted and stored at $\left.80^{\circ} \mathrm{C}\right)$.

\section{DNA Extraction and PCR-RFLP for detection of codon-268 mutations in the cytb gene}

Parasite genomic DNA was extracted from blood samples collected on filter paper using the chelex extraction method as described by Plowe and others[32]. Part of the DNA extracted from each sample was used immediately for PCR and the rest was stored at $-20^{\circ} \mathrm{C}$. The $P$. falciparum mitochondrial cytb gene (GenBank accession no. M99416) was amplified by nested polymerase chain reaction and analyzed by restriction fragment length polymorphisms (RFLP). A nested PCR was designed using Cytb1 and $C y t b 2$ as primary amplification primers and 3 different pairs of nested primers (Cytb2/Cytb6, Cytb2/Cytb7 and Cytb3/Cytb5) to distinguish the 3 known polymorphisms at codon 268 (Tyr268, Ser268 and Asn268). Primers sequences, primary and nested PCR conditions and procedures were performed as described previously by Schwobel and colleagues [25]. The product of each second round PCR was electrophoresed on 2\% agarose gel and visualized under UV transillumination following staining with ethidium bromide.

RLFP analysis of each $c y t b$ secondary amplification product was performed by digesting $5 \mu \mathrm{L}$ of each PCR product with the appropriate restriction enzyme and its buffer in a total volume $15 \mu \mathrm{L}$ and incubated at $37^{\circ} \mathrm{C}$ over night. The result was detected by electrophoresis in ethidium bromide-stained agarose gel (NuSieve ${ }^{\circledast}$ 3:1, Cambrex Bioscience Rockland Inc, ME, USA).

For detection of the wild-type Tyr268 allele at position $268,5 \mu \mathrm{L}$ of the secondary amplification product using the primer pair $C y t b 3 / C y t b 5$, was mixed with $1 \mathrm{U}$ of the restriction enzyme NsiI (New England Biolabs, Beverly,
MA). The enzyme cuts the wild-type allele (Tyr268) and mutant Asn268 but not the mutant Ser268 allele. Detection of mutant Ser268 allele was performed by digesting 5 $\mu \mathrm{L}$ of the $171 \mathrm{bp}$ region amplified using the primer pair Cytb2/Cytb2 with $1 \mathrm{U}$ of the restriction enzyme AlwNI (New England Biolabs, Beverly, MA). AlwNI cuts the mutant Ser268 allele but not the wild-type Tyr268 or the mutant Asn268 allele. The mutant Asn268 allele was detected by mixing $5 \mu \mathrm{L}$ of the secondary amplification product (174 bp) using Cytb2/Cytb7 with $1 \mathrm{U}$ of SspI (New England Biolabs, Beverly, MA). The enzyme cuts the wildtype Tyr268 allele or the mutant Ser268 allele but not the mutant Asn268 allele. DNA of P. falciparum clones 3D7 (Tyr268 allele), K1 (Tyr268 allele) and NGATV0l (Asn268 allele) strain were used as controls.

\section{Clonal analysis of PCR products and DNA sequencing}

PCR amplified products were cloned into TopoTA ${ }^{\oplus}$ vector (In vitrogene, San Diego, CA) and transfected into E. coli. Cells were grown overnight in terrific broth and Plasmid DNA was isolated using the SNAP Gel Purification Kit (Invitrogen, Carlsbad, CA). Samples of plasmid DNA containing inserts of interest were purified using a QIAprep Spin Plasmid Kit, and then sequenced using ABI PRISM Big dye Terminator Kit at a commercial facility (Dana Farber Cancer Research Institute, Harvard University, Boston, MA). The $c y t b$ coding region of mitochondrial DNA from each clone was sequenced five times in both the forward and reverse direction using the vector primers M13 forward and M13 reverse. DNA and protein sequences alignment was performed using the SeqMan ${ }^{\mathrm{TM}}$ and MegAlign ${ }^{\mathrm{TM}}$ (Seqwright, Houston, TX; DNASTAR, Madison WI) and MUSCLE [33] protein multiple sequence alignment softwares. P. falciparum clones 3D7 (Tyr268 allele), K1 (Tyr268 allele) and NGATV0l (Asn268 allele) strain were used as controls.

\section{Results}

A total of 309 samples were obtained from patients in Nigeria (118), Malawi (93) and Senegal (98). Out these samples, 295 (Nigeria 111; Malawi 91 and Senegal 93) were successfully tested for two different mutations on codon 268 of the parasite's cytb gene, which has been associated previously with AP treatment failure [12,20,2227]. Seven (7), 2 and 3 patient samples from Nigeria, Malawi and Senegal respectively did not yield PCR products. Patients characteristics are presented in Table 1. All patients were Africans resident of malaria endemic areas of West Africa (Nigeria and Senegal) and East Africa (Malawi) where AP is neither used for chemoprophylaxis nor for treatment of malaria.

In the parasite populations studied, PCR-RFLP results revealed no $P$. falciparum isolate from Nigeria, Senegal or Malawi with the mutant Ser268 allele in the cytb gene. All 
Table I: Characteristics of patients from whom samples were used for detection of cytb mutations at codon 268.

\begin{tabular}{lcc}
\hline Country & Number of patients & Age range (years) \\
\hline Nigeria & 111 & $1-12$ \\
Malawi & 91 & $0.5-25$ \\
Senegal & 93 & $3-70$ \\
\hline
\end{tabular}

isolates from Senegal and Malawi harboured the wildtype $c y t b$ Tyr268 allele. In addition, none of the isolates obtained from these 2 study sites showed the mutant $c y t b$ Asn268 allele.

Surprisingly, five isolates out of the 111 samples obtained from Nigerian patients showed the mutant $c y t b$ Asn268 allele. The resulting pattern after restriction enzyme digest of some of these five samples is shown in Figure 1. SspI cut the 174 bp product of the nested PCR into two fragments (150 bp and $24 \mathrm{bp}$ ) in presence of the TAT (Tyr) wild-type codon, while the mutant AAT (Asn) codon remained uncut. Fragment sizes between the wild-type $c y t b$ Tyr268 and mutant $c y t b$ Asn 268 differed by 24 bp (Figure 1). One (1) out of the five (5) samples that revealed the mutant Asn 268, showed a mixed (Tyr268 and Asn268) pattern, consisting of wild-type and mutant alleles at codon 268 . The presence of these mutations was further confirmed by sequencing. Sequencing data (Figure 2) confirmed the presence of the Asn 268 mutation in all the five samples from which the mutant alleles were detected by RFLP.

\section{Discussion}

In this study, the background/baseline prevalence of AP associated resistance mutations in $P$. falciparum $c y t b$ gene in isolates from three distinct geographical areas of Africa where the drug has not been introduced for the treatment of $P$. falciparum malaria was determined. The data from the study provides the very first evidence of the presence of $c y t b$ Tyr268Asn mutation in unexposed $P$. falciparum isolates from Africa.

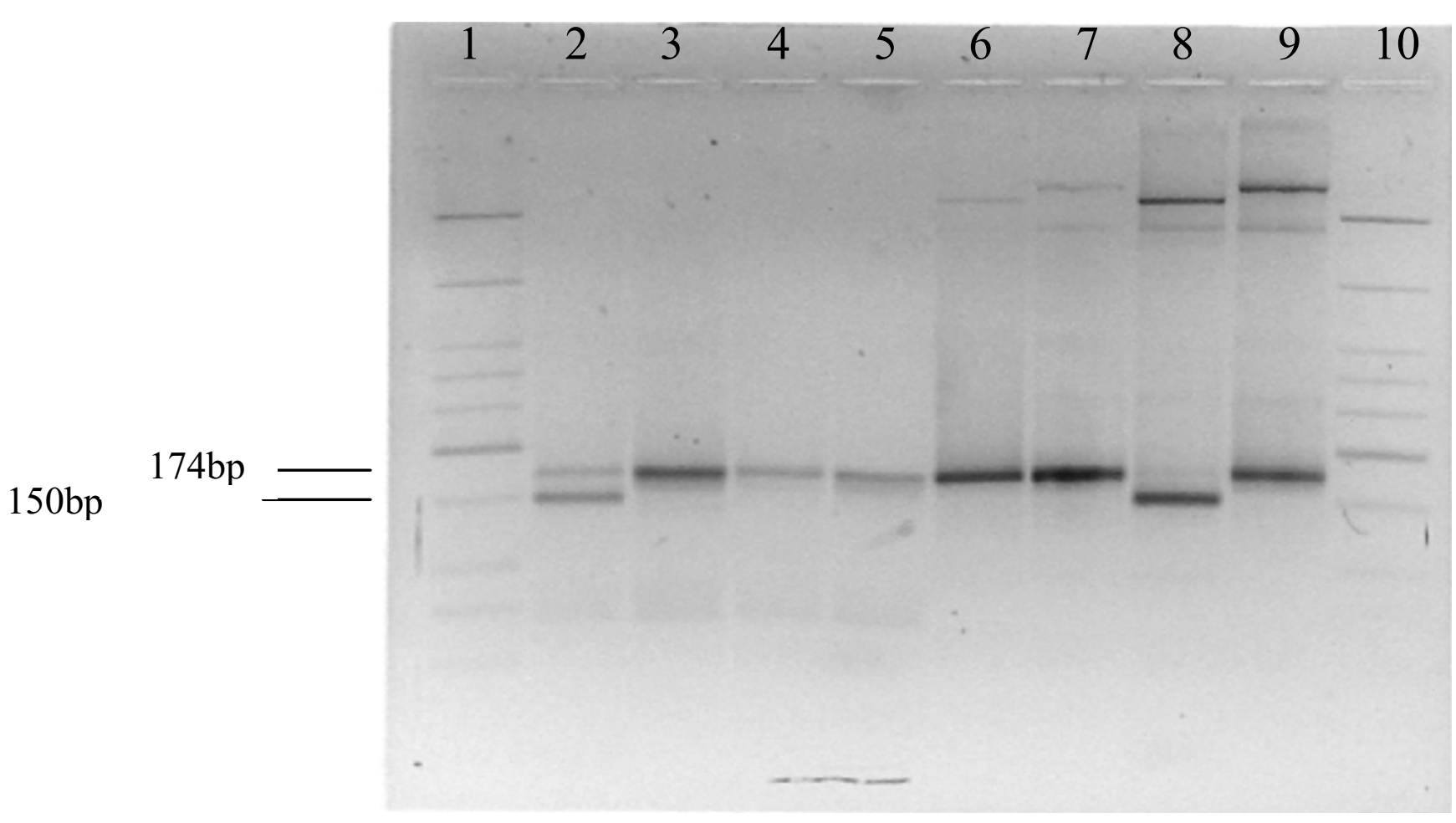

\section{Figure I}

Detection of Asn268 mutation in cytochrome b gene in $P$. falciparum by Restriction digest method. I74 bp amplification products with the secondary amplification primer pair cytb2/cytb7 (lanes 3, 5, 7, 9) digested with Sspl (lanes 2, 4, 6, 8) and were run on $2 \%$ NuSieve ${ }^{\circledR}$ 3:I agarose gel. DNA from NGATV0 I containing the AAT (Asn) mutation remains uncut (lane 6), while DNA from $\mathrm{KI}$ containing the TAT (Tyr) wild-type codon is digested (I50 bp) by the enzyme (lane 8). DNA from patient ID0I I showed a mixed infection consisting both the TAT (Tyr) wild-type digested (I50 bp) and mutant undigested (I74 bp) codons (lane 2). Patient ID024 had parasites harboring the mutant (Asn268) allele of cytb as their DNA remained uncut (lane 4) by the enzyme. Lanes I and 10 represent the low molecular weight DNA ladder (New England Biolabs, Beverly, MA) used as a marker for the electrophoresis 


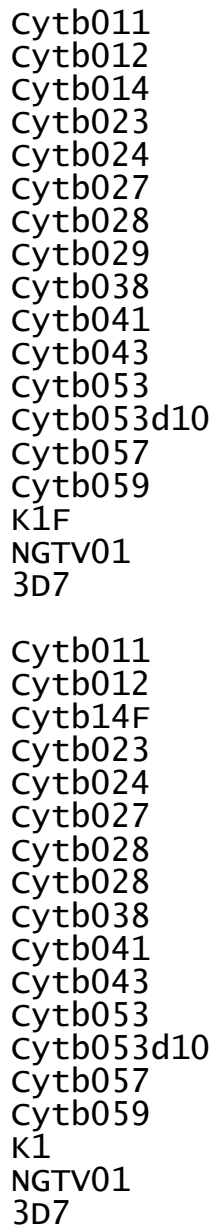

Cytb011 cytb012 cytb024 Cytb027 cytb038 cytb041 cytb043 cytb053d10 cytb057 cytb059 NGTV01 cytb14F cytb023 cytb028 cytb028 cytb038 cytb043 cytb053 cytb053d10 cytb057 cytb059 3D7
GYTVSDPTIKRFFVLHFILPFIGLCIVFIHIFFLHLHGSTNPLGYDTALKMPFYPNLL 215 GYTVSDXTIKRFFVLHFILPFIGLCIVFIHIFFLHLHGSTNPLGYDTALKIPFYPNLL 215 GYTVSDPTIKRFFVLHFILPFIGLCIVFIHIFFLHLHGSTNPLGYDTALKIPFYPNLL 215 GYTVSDPTIKRFFVLHFILPFIGLCIVFIHIFFLHLHGSTNPLGYDTALKIPFYPNLL 215 GYTVSDPTIKRFFVLHFILPFIGLCIVFIHIFFLHLHGSTNPLGYDTALKIPFYPNLL 215 GYTVSDPTIKRFFVLHFILPFIGLCIVFIHIFFLHLHGSTNPLGYDTALKIPFYPNLL 215 GYTVSDPTIKRFFVLHFILPFIGLCIVFIHIFFLHLHGSTNPLGYDTALKIPFYPNLL 215 GYTVSDPTIKRFFVLHFILPFIGLCIVFIHIFFLHLHGSTNPLGYDTALKIPFYPNLL 215 GYTVSDPTIKRFFVLHFILPFIGLCIVFIHIFFLHLHGSTNPLGYDTALKIPFYPNLL 215 GYTVSDPTIKRFFVLHFILPFIGLCIVFIHIFFLHLHGSTNPLGYDTALKIPFYPNLL 215 GYTVSDPTLKRFFVLHFILPFIGLCIVFIHIFFLHLHGSTNPLGYDTALKIPFYPNLL 215 GYTVSDPTLKRFFVLHFILPFIGLCIVFIHIFFLHLHGSTNPLGYDTALKIPFYPNLL 215 GYTVSDPTIKRFFVLHFILPFIGLCIVFIHIFFLHLHGSTNPLGYDTALKIPFYPNLL 215 GYTVSDPTIKRFFVLHFILPFIGLCIVFIHIFFLHLHGSTNPLGYDTALKIPFYPNLL 215 GYTVSDPTIKRFFVLHFILPFIGLCIVFIHIFFLHLHGSTNPLGYDTALKIPFYPNLL 215 GYTVSDPTIKRFFVLHFILPFIGLCIVFIHIFFLHLHGSTNPLGYDTALKIPFYPNLL 215 GYTVSDPTIKRFFVLHFILPFIGLCIVFIHIFFLHLHGSTNPLGYDTALKIPFYPNLL 215 GYTVSDPTIKRFFVLHFILPFIGLCIVFIHIFFLHLHGSTNPLGYDTALKIPFYPNLL 215

SLDVKGFNNVIILFLIQSLFGIIPLSHPDNAIVVNTYVTPSQIVPEWYFLPFNAMLKTVPSKPA 279 SLDVKGFNNVIILFLIQSLFGIIPLSHPDNAIVVNTYVTPSQIVPEWYFLTFYAMLKTVPSKPA 279 SLDVKGFNNVIILFLIQSLFGIIPLSHPDNAIVVNTYVTPSQIVPEWYFLPFYAMLKTVPSKPA 279 SLDVKGFNNVIILFLIQSLFGIIPLSHPDNAIVVNTYVTPSQIVPEWYFLPFYAMLKTVPSKPA 279 SLDVKGFNNVIILFLTQSLFGIIPLSHPDNAIVVNTYVTPSQIVPEWHFLPFNAMLKTVPSKPA 279 SLDVKGFNNVIILFLIQSLFGIIPLSHPDNAIVVNTYVTPSQIVPEWYFLPFNAMLKTVPSKPA 279 SLDVKGFNNVIILFLIQSLFGIIPLSHPDNAIVVNTYVTPSQIVPEWYFLPFYAMLKTVPSKPA 279 SLDVKGFNNVIILFLIQSLFGIIPLSHPDNAIVVNTYVTPSQIVPEWYFLPFYAMLKTVPSKPA 279 SLDVKGFNNVIILFLIQSLFGIIPLSHPDNAIVVNTYVTPSQIVPEWYFLPFNAMLKTVPSKPA 279 SLDVKGFNNVIILFLIQSLFGIIPLSHPDNAIVVNTYVTPSQIVPEWYFLPFYAMLKTVPSKPA 279 SLDVKGFNNVIILFLIQSLFGIIPLSHPDNAIVVNTYVTPSQIVPEWYFLPFYAMLKTVPSKPA 279 SLDVKGFNNVIILFLIQSLFGI IPLSHPDNAIVVNTYVTPSQIVPEWYFLPFYAMLKTVPSKPA 279 SLDVKGFNNVIILFLIQSLFGIIPLSHPDNAIVVNTYVTPSQIVPEWYFLPFNAMLKTVPSKPA 279 SLDVKGFNNVIILFLIQSLFGIIPLSHPDNAIVVNTYVTPSQIVPEWYFLPFYAMLKTVPSKPA 279 SLDVKGFNNVIILFLIQSLFGIIPLSHPDNAIVVNTYVTPSQIVPEWYFLPFYAMLKTVPSKPA 279 SLDVKGFNNVIILFLIQSLFGIIPLSHPDNAIVVNTYVTPSQIVPEWYFLPFYAMLKTVPSKPA 279 SLDVKGFNNVIILFLIQSLFGIIPLSHPDNAIVVNTYVTPSQIVPEWYFLPFNAMLKTVPSKPA 279 SLDVKGFNNVIILFLIQSLFGIIPLSHPDNAIVVNTYVTPSQIVPEWYFLPFYAMLKTVPSKPA 279

\section{Figure 2}

Multiple sequences alignment of cytochrome b gene (residues 137 to 279) of some Nigerian isolates of $P$. falciparum. Highlighted are residues 268 with amino acid changes from the wild-type tyrosine $(Y)$ to the mutant asparagine $(N)$ allele associated previously with atovaquone resistance in Plasmodium falciparum. In addition residue 266 in patient ID (Cytb0 I2) where Pro (P) is changed to Thr (T) is also highlighted. Sequences of the atovaquone resistant (NGTV0I) and sensitive (KI and 3D7) control strains are also present.

In 2002, the first case of in vivo resistance to AP was reported in a non-immune European traveler returning from Nigeria [22]. Molecular and phenotypic characterizations of the isolate of $P$. falciparum obtained from the patient showed a Tyr to Asn mutation at codon 268, resulting in a 800 fold increase of the $\mathrm{IC}_{50}$ [22]. However, Fivelman and colleagues [22] argued that since AP combination is not yet used in West Africa, it is unlikely that the patient was initially infected with an atovaquone resistant strain of P. falciparum. Thus, the mutation in the parasites $c y t b$ gene would have occurred under AP pressure. The data from this study is contradictory to the argument raised by Fivelman and colleagues [22], since AP combination is still not used in Nigeria and yet some $P$. falci- parum from the same locality harbor mutant Asn 268 allele.

The reasons behind the emergence of the mutant Asn268 allele of $c y t b$ gene is indigenous $P$. falciparum unexposed to AP combination is remain unclear. It has been suggested that the mutations at codon 268 of $c y t b$ gene in unexposed $P$. falciparum populations may occur either naturally [11] or through prior exposure to related drugs [27]. Trimethoprim-sulfametoxazole is often used for treatment of Pneumocystis carinii pneumonia in HIV patients in Nigeria. However, for patients who react to this sulfa-based combination, atovaquone is given as a rescue therapy. It is possible that treatment with atovaquone in this category 
of patients could select for mutant Asn cytb268 in indigenous $P$. falciparum population in this area where HIV patients could be co-infected with malaria, although there is no clear evidence of this selection process. A recent report [34] has shown that the percentage of individuals with Pneumocystis carinii pneumonia who are co-infected with other pathogens is very high (ranging from $20 \%$ to $70 \%$ ) in Africa and other developing countries.

Another potential explanation for the emergence of $P$. falciparum with cytb Asn268 mutation in Nigeria could be due to the selection of this allele by AP in the large number non-immune (European and Americans) workers (under AP chemoprophylaxis) in the Nigerian oil industry. Investigations are currently underway to determine if AP chemoprophylaxis among non-immune oil workers is exerting some selective pressure on indigenous strains of P. falciparum.

The detection and confirmation of mutant cytb Asn268 allele in some P. falciparum isolates from Nigeria is a matter of serious concern since these parasites may spread to other neighboring African countries where P. falciparum resistance to atovaquone or AP combination has not been reported. Recent studies $[7,12,22,23]$ confirmed genetically and biochemically the linkage of atovaquone/AP resistance to $c y t b$ mutations (Tyr268Ser and Tyr268Asn) and the molecular mechanisms of parasites resistance this drugs. Tyr268 is a conserved bulky hydrophobic contact of atovaquone in the Qo II region of the ubiquinol oxidation site of the $c y t b c 1$ complex. Substitution of Tyr268 by a less bulky Asn268 not only reduces the volume of the binding pocket, but also decreases the affinity and binding of atovaquone and thus leads to drug resistance $[22,35]$. Of interest, is the presence in one sample (Cytb012) of an addition mutation at position 266, where Pro $(\mathrm{P})$ is substituted to Thr $(\mathrm{T})$. The presence and the role of this mutation within the atovaquone binding site needs further investigation, as the presence of additional mutations within the ubiquinone reduction site has been previously suggested to be involved in high level resistance to the drug [7].

Efforts are currently underway to conduct a more elaborate study where genotypic and phenotypic characterization of AP resistant isolates of $P$. falciparum will be determined especially in Nigeria.

\section{Conclusion}

This study reports for the first time the presence of Tyr268Asn mutation in unexposed $P$. falciparum isolates from Nigeria. The emergence in African $P$. falciparum isolates of Tyr268Asn mutation which is associated with AP resistance raises serious concerns about the long-term use of this drug for malaria chemoprophylaxis in non- immune travelers visiting West Africa. Continuous monitoring of AP resistant $P$. falciparum in Africa is warranted for the rational use of this valuable antimalarial drug especially in non-immune travelers.

\section{Authors' contributions}

HCT, GOG, OAF, AS, KED, MKW, WFD and AMJO contributed to the conception and design of the study. HCT, GOG, OAF, MD, OS and AS participated in enrolment of patients and sampling. HCT, GOG, OAF, MD, OS performed molecular typing of isolates and analysis of data. All the authors contributed to writing the manuscript. All the authors read and approved the final version that was submitted for publication.

\section{Disclaimer}

The opinions or assertions contained herein are the private views of the authors (MKW and KED), and are not to be construed as official, or as reflecting true views of the Department of the Army or the Department of Defense.

\section{Acknowledgements}

The authors thank all the patients, their parents/guardians for volunteering to participate in the studies. We thank Prof. David Warhurst at the London School of Hygiene and Tropical Medicine for providing the $P$. falciparum strain NGATVOl genomic DNA. We also thank the Malaria Research and Reference Reagent Resource Centre (MR4) for providing genomic DNA from $P$. falciparum $\mathrm{KI}$ and $3 \mathrm{D} 7$ strains. This study was supported by a grant from the Fogarty International Centre (FIC/NIH), the Multilateral Initiative for Malaria in Africa (MIM)/TDR, the UNICEF/UNDP/World Bank/WHO/ TDR, the Harvard Malaria Initiative and the International Atomic Energy Agency (IAEA). C.T Happi is supported by a Fogarty International Research Collaboration Award (FIRCA) no. NIH RO3TW006298-0IAI, the IAEA project RAF/0625 and the WHO/TDR/PAG/South-South Initiative project ID A50337. GOG is supported by the MIM/TDR project ID A20239. OS is supported by the Fogarty International Research Training Grant TW0I5030 . DM is supported by The American Society of Tropical Medicine and Hygiene Tropical Infectious Disease Fellowship provided for by the Burroughs Wellcome and Ellison Medical Foundations.

\section{References}

I. Milhous WK: Development of new drugs for chemoprophylaxis of malaria. Med Trop (Mars) 200I, 6 I:48-50.

2. Matsuu A, Koshida Y, Kawahara M, Inoue K, Ikadai H, Hikasa $Y$, Okano S, Higuchi S: Efficacy of atovaquone against Babesia gibsoni in vivo and in vitro. Vet Parasitol 2004, I 24:9-18.

3. Araujo FG, Huskinson J, Remington JS: Remarkable in vitro and in vivo activities of the hydroxynaphthoquinone $566 \mathrm{C80}$ against tachyzoites and tissue cysts of Toxoplasma gondii. Antimicrob Agents Chemother 1991, 35:293-299.

4. Fry M, Pudney M: Site of action of the antimalarial hydroxynaphthoquinone, 2-[trans-4-(4'-chlorophenyl) cyclohexyl]-3hydroxy-I,4-naphthoquinone $(566 \mathrm{C} 80)$. Biochem Pharmacol 1992, 43:1545-1553.

5. Srivastava IK, Rottenberg H, Vaidya AB: Atovaquone, a broad spectrum antiparasitic drug, collapses mitochondrial membrane potential in a malarial parasite. J Biol Chem 1997, 272:396I-3966

6. Kessl J], Lange BB, Merbitz-Zahradnik T, Zwicker K, Hill P, Meunier B, Palsdottir H, Hunte C, Meshnick S, Trumpower BL: Molecular basis for atovaquone binding to the cytochrome bcl complex. J Biol Chem 2003, 278:313|2-31318. 
7. Kessl J], Ha KH, Merritt AK, Lange BB, Hill P, Meunier B, Meshnick SR, Trumpower BL: Cytochrome b mutations that modify the ubiquinol-binding pocket of the cytochrome bcl complex and confer anti-malarial drug resistance in Saccharomyces cerevisiae. J Biol Chem 2005, 280: I7|42-I7|48.

8. Chiodini PL, Conlon CP, Hutchinson DB, Farquhar JA, Hall AP, Peto $\mathrm{TE}$, Birley $\mathrm{H}$, Warrell DA: Evaluation of atovaquone in the treatment of patients with uncomplicated Plasmodium falciparum malaria. J Antimicrob Chemother 1995, 36: 1073-1078.

9. Looareesuwan S, Viravan C, Webster HK, Kyle DE, Hutchinson DB, Canfield CJ: Clinical studies of atovaquone, alone or in combination with other antimalarial drugs, for treatment of acute uncomplicated malaria in Thailand. Am J Trop Med Hyg 1996, 54:62-66.

10. Looareesuwan S, Chulay JD, Canfield CJ, Hutchinson DB: Malarone (atovaquone and proguanil hydrochloride): a review of its clinical development for treatment of malaria. Malarone Clinical Trials Study Group. Am J Trop Med Hyg 1999, 60:533-54I.

II. Musset L, Pradines B, Parzy D, Durand R, Bigot P, Le Bras J: Apparent absence of atovaquone/proguanil resistance in 477 Plasmodium falciparum isolates from untreated French travellers. J Antimicrob Chemother 2006, 57: I I0-I I5.

12. Musset L, Bouchaud O, Matheron S, Massias L, Le Bras J: Clinical atovaquone-proguanil resistance of Plasmodium falciparum associated with cytochrome b codon 268 mutations. Microbes and Infect 2006. doi: 10.1016/j.micinf.2006.07.0I I

13. Srivastava I, Vadiya A: A mechanism for the synergistic antimalarial action of atovaquone and proguanil. Antimicrob Agents Chemother 1999, 43:1334-1339.

14. Anabwani G, Canfield CJ, Hutchinson DB: Combination atovaquone and proguanil hydrochloride vs. halofantrine for treatment of acute Plasmodium falciparum malaria in children. Pediatr Infect Dis J 1999, 18:456-46I.

15. Mulenga M, Sukwa TY, Canfield CJ, Hutchinson DB: Atovaquone and proguanil versus pyrimethamine/sulfadoxine for the treatment of acute falciparum malaria in Zambia. Clin Ther 1999, 21:84|-852.

16. Llanos-Cuentas A, Campos P, Clendenes M, Canfield CJ, Hutchinson DB: Atovaquone and proguanil hydrochloride compared with chloroquine or pyrimethamine/sulfodaxine for treatment of acute Plasmodium falciparum malaria in Peru. Braz J Infect Dis 200I, 5:67-72.

17. Camus D, Djossou F, Schilthuis HJ, Hogh B, Dutoit E, Malvy D, Roskell NS, Hedgley C, De Boever EH, Miller GB: Atovaquone-proguanil versus chloroquine-proguanil for malaria prophylaxis in nonimmune pediatric travelers: results of an international, randomized, open-label study. Clin Infect Dis 2004, 38: 1716-1723.

18. Petersen $E$ : The safety of atovaquone/proguanil in long-term malaria prophylaxis of non-immune adults. J Travel Med 2003, I0(SuppI I):SI3-15. discussion S2I

19. Srivastava IK, Morrisey JM, Darrouzet E, Daldal F, Vaidya AB: Resistance mutations reveal the atovaquone-binding domain of cytochrome b in malaria parasites. Mol Microbiol 1999, 33:704-7II.

20. Korsinczky M, Chen N, Kotecka B, Saul A, Rieckmann K, Cheng Q: Mutations in Plasmodium falciparum cytochrome $b$ that are associated with atovaquone resistance are located at a putative drug-binding site. Antimicrob Agents Chemother 2000, 44:2100-2108.

21. Suswam E, Kyle D, Lang-Unnasch N: Plasmodium falciparum: the effects of atovaquone resistance on respiration. Exp Parasitol 200I, 98: I80-I87.

22. Fivelman QL, Butcher GA, Adagu IS, Warhurst DC, Pasvol G: Malarone treatment failure and in vitro confirmationof resistance of Plasmodium falciparum isolate from Lagos, Nigeria. MalarJ 2002, I:I.

23. Fivelman QL, Adagu IS, Warhurst DC: Modified fixed-ratio isobologram method for studying in vitro interactions between atovaquone and proguanil or dihydroartemisinin against drug-resistant strains of Plasmodium falciparum. Antimicrob Agents Chemother 2004, 48:4097-4I02.

24. Farnert A, Lindberg J, Gil P, Swedberg G, Berqvist Y, Thapar MM, Lindegardh N, Berezcky S, Bjorkman A: Evidence of Plasmodium falciparum malaria resistant to atovaquone and proguanil hydrochloride: case reports. Bmj 2003, 326:628-629.
25. Schwobel B, Alifrangis M, Salanti A, Jelinek T: Different mutation patterns of atovaquone resistance to Plasmodium falciparum in vitro and in vivo: rapid detection of codon 268 polymorphisms in the cytochrome $b$ as potential in vivo resistance marker. Malar J 2003, 2:5.

26. David KP, Alifrangis M, Salanti A, Vestergaard LS, Ronn A, Bygbjerg IB: Atovaquone/proguanil resistance in Africa: a case report. Scand J Infect Dis 2003, 35:897-898.

27. Kuhn S, Gill MJ, Kain KC: Emergence of atovaquone-proguanil resistance during treatment of Plasmodium falciparum malaria acquired by a non-immune north American traveller to west Africa. Am J Trop Med Hyg 2005, 72:407-409.

28. Wichmann $O$, Muehlberger N, Jelinek T, Alifrangis M, Peyerl-Hoffmann G, Muhlen M, Grobusch MP, Gascon J, Matteelli A, Laferl H, Bisoffi Z, Ehrhardt S, Cuadros J, Hatz C, Gjorup I, McWhinney P, Beran J, da Cunha S, Schulze M, Kollaritsch H, Kern P, Fry G, Richter J, European Network on Surveillance of Imported Infectious Diseases: Screening for mutations related to atovaquone/proguanil resistance in treatment failures and other imported isolates of Plasmodium falciparum in Europe. J Infect Dis 2004, 190:154I-1546.

29. Gil JP, Nogueira F, Stromberg-Norklit J, Lindberg J, Carrolo M, Casimiro C, Lopes D, Arez AP, Cravo PV, Rosario VE: Detection of atovaquone and Malarone ${ }^{\circledR}$ resistance conferring mutations in Plasmodium falciparum cytochrome b gene (cytb). Mol Cell Probes 2003, 17:85-89.

30. Pimentel S, Nogueira F, Benchimol C, Quinhentos V, Bom J, Varandas L, do Rosario V, Bernardino L: Detection of atovaquone-proguanil resistance conferring mutations in Plasmodium falciparum cytochrome b gene in Luanda, Angola. Malar J 2006, 5:30.

31. Happi CT, Gbotosho GO, Folarin OA, Akinboye DO, Yusuf BO, Ebong OO, Sowunmi A, Kyle DE, Milhous W, Wirth DF, Oduola AMJ: Polymorphisms in Plasmodium falciparum dhfr and dhps genes and age related in vivo sulfadoxine-pyrimethamine resistance in malaria-infected patients from Nigeria. Acta Trop 2005, 95:183-193.

32. Plowe CV, Djimde A, Bouare M, Doumbo O, Wellems TE: Pyrimethamine and proguanil resistance-conferring mutations in Plasmodium falciparum dihydrofolate reductase: polymerase chain reaction methods for surveillance in Africa. Am J Trop Med Hyg 1995, 52:565-568.

33. Edgar RC: MUSCLE: multiple sequence alignment with high accuracy and high throughput. Nucleic Acids Res 2004, 32:1792-1797.

34. Fisk DT, Meshnick S, Kazanjian PH: Pneumocystis carinii pneumonia in patients in the developing world who have acquired immunodeficiency syndrome. Clin Infect Dis 2003, 36:70-78.

35. Basselin M, Hunt SM, Abdala-Valencia $H$, Kaneshiro ES: Ubiquinone synthesis in mitochondrial and microsomal subcellular fractions of Pneumocystis spp.: differential sensitivities to atovaquone. Eukaryot Cell 2005, 4: | 483-| 492.

Publish with Bio Med Central and every scientist can read your work free of charge

"BioMed Central will be the most significant development for disseminating the results of biomedical research in our lifetime. "

Sir Paul Nurse, Cancer Research UK

Your research papers will be:

- available free of charge to the entire biomedical community

- peer reviewed and published immediately upon acceptance

- cited in PubMed and archived on PubMed Central

- yours - you keep the copyright

Submit your manuscript here:

http://www.biomedcentral.com/info/publishing_adv.asp
BioMedcentral 